\title{
Pembuatan Aplikasi Point of Sale Toko Cabang Perusahaan Torani Menggunakan Framework CodeIgniter
}

\author{
Jodhi Sugihartono, Kodrat Iman Satoto, Eko Didik Widianto \\ Program Studi Sistem Komputer, Fakultas Teknik, Universitas Diponegoro \\ Jl. Prof. Sudharto, Tembalang, Semarang, Indonesia \\ E-mail : jodhisugihartono25@gmail.com
}

\begin{abstract}
Abstrak - Dalam Industri yang semakin pesat perkembangannya, proses transaksi dan keluar masuknya barang perlu dicatat, ini diperlukan untuk mempermudah suatu perusahaan dalam mengontrol jumlah nilai pemasukan dan pengeluaran. Data fisik merupakan sesuatu yang mudah hilang, dimana dalam pendataan juga dimungkinkan adanya Human Error, salah satu akibatnya adalah dapat menyebabkan suatu perbedaan data, kesalahan pendatan, kekurangan pemesanan, dan kesalahan perhitungan jumlah pemasukan dan pengeluaran. Aplikasi ini dapat membantu perusahaan dalam pendataan barang dan transaksi menjadi lebih mudah dilakukan. Pemesanan barang pun dapat dilakukan melalui apikasi tanpa harus memesan dengan menggunakan telepon. Aplikasi ini dibuat dengan menggunakan bahasa pemrograman PHP, Jquery, database MySQL, dan framework CodeIgniter.
\end{abstract}

Kata Kunci : Point of Sale, PHP, MySQL, CodeIgniter.

\section{PENDAHULUAN}

$\mathrm{D}^{\mathrm{s}}$ lam perkembangan teknologi yang pesat, komunikasi dan pertukaran data yang cepat sangat diperlukan oleh suatu lembaga maupun. Dengan adanya aplikasi point of sale ini dimungkinkan dapat melakukan suatu pekerjaan pendataan maupun transaksi barang dengan cepat, tepat dan lebih efektif serta efisien.

Pada suatu perusahaan yang memiliki relasi kerjasama dengan pihak luar lainnya, khususnya untuk perusahaan yang bergerak di bidang industri perdagangan, jumlah keluar masuknya barang dan proses pemesanan barang yang habis di setiap toko cabang yang dimiliki perusahaan perlu didata sehingga setiap transaksi yang dilakukan dapat diawasi dan dicek dengan mudah oleh toko itu sendiri maupun oleh perusahaan. Pendataan barang dan transaksi jual beli secara manual dapat dilakukan, namun ini memiliki banyak kekurangan. Faktor human error merupakan suatu faktor yang dapat mengakibatkan banyak masalah, seperti terjadinya kesalahan pendataan, kekurangan pemesanan, kesalahan penghitungan pemasukan dan pengeuaran, dan lain sebagainya, yang mana ini dapat menyebabkan kerugian bagi perusahaan tersebut.

Aplikasi point of sale ini dibuat untuk meminimalisasi pendataan barang dan transaksi secara manual serta penggunaan telepon untuk melakukan pemesanan terhadap distributor. Dengan adanya aplikasi ini, maka setiap pendataan barang di toko dan pemesanan barang yang habis di toko dapat dilakukan secara cepat dengan mengacu pada database yang ada pada perusahaan, sehingga ini akan membuat pekerja melakukan pekerjaan secara efektif dan efisien.

Sistem Point of Sale (POS) adalah sebuah sistem aplikasi yang diterapkan pada bisnis minimarket ataupun pertokoan untuk menangani pengolahan data transaksi pembelian (purchases), transaksi penjualan eceran (retails), transaksi hutang (liabilities), transaksi retur pembelian (purchase returns), dan pelaporan transaksi (reporting) yang secara umum penting dibutuhkan dalam pengambilan keputusan strategik oleh para pebisnis swalayan, organisasi, atau perusahaan yang berskala kecil dan menengah. ${ }^{[4]}$
Manfaat dari sistem point of sale untuk sebuah organisasi salah satunya adalah untuk mengolah transaksitransaksi, mengurangi biaya dan menghasilkan pendapatan sebagai salah satu produk atau pelayanan mereka. Perusahaan menggunakan sistem point of sale untuk mempertahankan persediaan pada tingkat paling rendah agar konsistem dengan jenis barang yang tersedia. ${ }^{[1]}$

Tujuan dilakukan pembuatan aplikasi point of sale penelitian dalam Tugas Akhir ini adalah untuk merancang sistem pendataan barang yang dapat digunakan untuk memudahkan pengecekan jumlah stok barang di toko, merancang sistem pemesanan barang di toko cabang untuk memudahkan pemesanan barang yang habis di toko, merancang sistem kasir untuk memudahkan proses transaksi jual beli dengan pelanggan toko, dan membagi sistem menjadi 3 bagian menu untuk membagi tugas antara admin, pegawai, dan petugas kasir secara terstruktur.

Dalam pembuatan Tugas Akhir ini pembahasan masalah memiliki batasan permasalahan, antara lain pembuatan aplikasi point of sale ditujukan pada lingkup toko cabang perusahaan pemasok bahan olahan ikan mentah Torani Cirebon, pembuatan aplikasi point of sale toko cabang perusahaan Torani menggunakan framework CodeIgniter dan database MySQL, dan Hasil aplikasi akan disimulasikan di web browser secara offline maupun online.

\section{Metode Penelitian}

Sebuah sistem yang baik tidak lepas dari sebuah perancangan yang matang. Layaknya membuat sebuah bangunan, tentulah dibutuhkan sebuah blueprint agar bangunan yang akan dibuat nantinya dapat tepat sasaran dan tepat guna. Metode yang digunakan dalam perancangan aplikasi tugas akhir ini adalah metode Waterfall. Metode Waterfall terdiri dari spesifikasi (requirements), analisis (analysis), perancangan (design), implementasi (implementation), dan pengujian (testing). Proses dalam metode Waterfall digambarkan pada Gambar 1. 


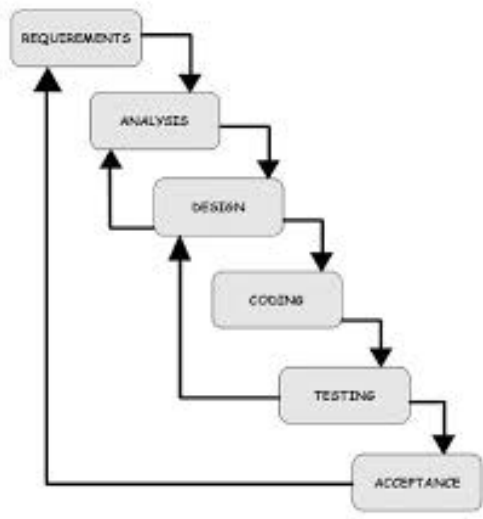

Gambar 1. Tahapan metode Waterfall

Tahap pertama yang dilakukan adalah spesifikasi kebutuhan, yang bertujuan untuk mengetahui masalah yang sedang terjadi yang ada pada toko cabang perusahaan Torani.

Tahap kedua adalah analisa kebutuhan, yang dilakukan untuk mencari solusi yang tepat untuk memecahkan masalah yang ada pada toko cabang perusahaan Torani seperti yang diketahui pada spesifikasi kebutuhan.

Tahap ketiga adalah perancangan aplikasi. Hasil analisa yang telah didapat sebelumnya dituangkan dalam perancangan untuk menentukan fungsi-fungsi apa saja yang nantinya terdapat dalam aplikasi tersebut untuk memenuhi kebutuhan aplikasi tertentu.

Setelah melewati tahap perancangan, pada tahap keempat, hasil dari rancangan yang sudah ada tersebut diimplementasikan ke dalam kode-kode program sehingga terbentuklah suatu aplikasi jadi yang siap pakai.

Tahap kelima adalah pengujian. Metode pengujian yang digunakan untuk menguji sistem adalah dengan menggunakan metode pengujian Black Box. Metode pengujian ini akan menguji seluruh komponen dan fungsionalitas sistem apakah perangkat lunak yang dibuat telah dapat berjalan dengan benar dan sesuai dengan tujuan yang ingin dicapai. Pengujian dilakukan terhadap aplikasi untuk mengidentifikasikan sekaligus memperbaiki kesalahan-kesalahan yang ada. Hasil dari tahapan ini adalah aplikasi yang sudah terbebas dari kesalahan-kesalahan, dapat berjalan sesuai dengan fungsinya, dan siap digunakan. ${ }^{[2]}$

\section{HASIL DAN PENGUJIAN}

Setelah melakukan wawancara dan pengamatan secara langsung dengan pihak terkait terhadap keadaan di toko Torani, maka didapat hasil spesifikasi kebutuhan dimana proses kerja dibagi menjadi beberapa tahapan yang tertuang dalam tabel berikut :

Tabel 1. Kesimpulan proses bisnis

\begin{tabular}{|c|c|c|}
\hline Proses & Informasi & Kendala \\
\hline $\begin{array}{l}\text { Pendaftaran } \\
\text { karyawan } \\
\text { baru }\end{array}$ & $\begin{array}{l}\text { Kode karyawan, } \\
\text { nama lengkap, } \\
\text { username, } \\
\text { password, } \\
\text { tanggal lahir, } \\
\text { alamat lengkap, } \\
\text { nomor telepon, } \\
\text { jabatan }\end{array}$ & $\begin{array}{l}\text { Proses pendaftaran masih } \\
\text { manual dan pencarian } \\
\text { data karyawan masih } \\
\text { dilakukan } \\
\text { mencari data } \\
\text { manual }\end{array}$ \\
\hline $\begin{array}{l}\text { Penambahan } \\
\text { Produk Baru } \\
\text { dan } \\
\text { Penambahan } \\
\text { Stok Barang }\end{array}$ & $\begin{array}{l}\text { Kode produk, } \\
\text { nama produk, } \\
\text { detail produk, } \\
\text { harga produk, } \\
\text { stok produk }\end{array}$ & $\begin{array}{l}\text { Proses pendataan barang } \\
\text { masih manual dengan } \\
\text { menggunakan } \\
\text { catatan }\end{array}$ \\
\hline
\end{tabular}

\begin{tabular}{|l|l|l|}
\hline $\begin{array}{l}\text { Pemesanan } \\
\text { barang ke } \\
\text { distrbutor }\end{array}$ & $\begin{array}{l}\text { Kode produk, } \\
\text { nama produk, } \\
\text { jumlah produk }\end{array}$ & $\begin{array}{l}\text { Pemesanan ke distributor } \\
\text { masih dilakukan via } \\
\text { telepon }\end{array}$ \\
\hline $\begin{array}{l}\text { Transaksi } \\
\text { kasir dengan } \\
\text { konsumen }\end{array}$ & $\begin{array}{l}\text { Kode produk, } \\
\text { nama produk, } \\
\text { harga produk, } \\
\text { jumlah, total } \\
\text { harga }\end{array}$ & $\begin{array}{l}\text { Proses transaksi masih } \\
\text { dilakukan dengan manual } \\
\text { dan perhitungan barang } \\
\text { dan harga masih dihitung } \\
\text { satu per satu }\end{array}$ \\
\hline
\end{tabular}

Untuk memahami sifat dan fungsi sistem yang akan dibangun, analisa yang dilakukan harus memahami domain informasi, pembagian fungsi, dan tingkah laku yang diperlukan dan mengacu pada tahap sebelumnya. Sistem yang dibangun akan dapat digunakan oleh 3 aktor, yaitu administrator, pegawai, dan kasir. Deskripsi dari masing-masing aktor dapat dilihat adalah sebagai berikut :

Tabel 2. Deskripsi masing-masing aktor

\begin{tabular}{|l|l|l|}
\hline No & \multicolumn{1}{|c|}{ Aktor } & \multicolumn{1}{c|}{ Deskripsi } \\
\hline 1 & Admin & $\begin{array}{l}\text { Admin atau selaku manajer memiliki } \\
\text { hak akses tertinggi untuk mengelola } \\
\text { data master yang ada dalam database, } \\
\text { memantau produk dan jumlah stok } \\
\text { produk, dan mengubah detail toko } \\
\text { cabang sebagai data utama untuk } \\
\text { alamat pemesanan kepada distributor. }\end{array}$ \\
\hline 2 & Pegawai & $\begin{array}{l}\text { Pegawai yang merupakan karyawan } \\
\text { pendataan barang dapat melakukan } \\
\text { penambahan atau perubahan suatu } \\
\text { produk, menambahkan stok suatu } \\
\text { produk, dan memesan produk kepada } \\
\text { distributor. Pegawai juga dapat melihat } \\
\text { stok barang masuk dan keluar dari toko } \\
\text { dan memantau laporan pemasukan dan } \\
\text { pengeluaran. }\end{array}$ \\
\hline 3 & Kasir & $\begin{array}{l}\text { Kasir hanya dapat melakukan transaksi } \\
\text { menggunakan barcode scanner untuk } \\
\text { memasukkan data barang yang dibeli } \\
\text { oleh konsumen ke dalam sistem. }\end{array}$ \\
\hline
\end{tabular}

Setelah mendeskripsikan prosedur-prosedur pada sistem yang akan digunakan oleh toko Torani, pihak toko Torani Cirebon menginginkan kondisi dimana terdapat pembagian untuk masing-masing aktor yang terlibat dalam menggunakan sistem. Setiap pembagian untuk masing-masing aktor memliki menu dan fungsi yang berbeda sesuai dengan kebutuhan masing-masing aktor seperti yang digambarkan dalam diagram use case seperti pada Gambar 2.

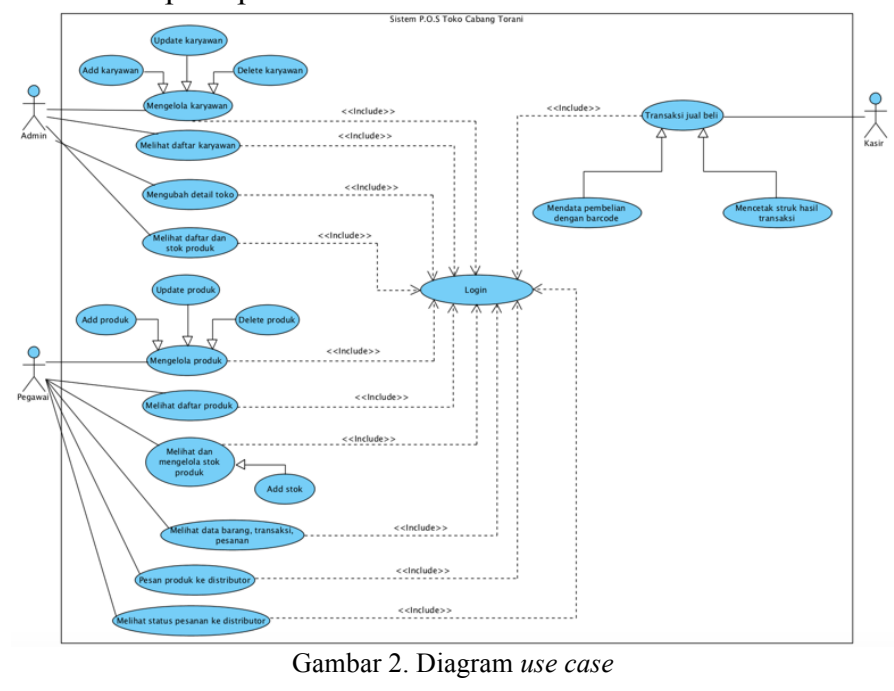

JTsiskom - 446 
Dari diagram use case yang telah digambarkan di atas, proses kerja dari masing-masing aktor dapat dijelaskan melalui sequence diagram. Berikut adalah sequence diagram login yang ditunjukkan pada Gambar 3.

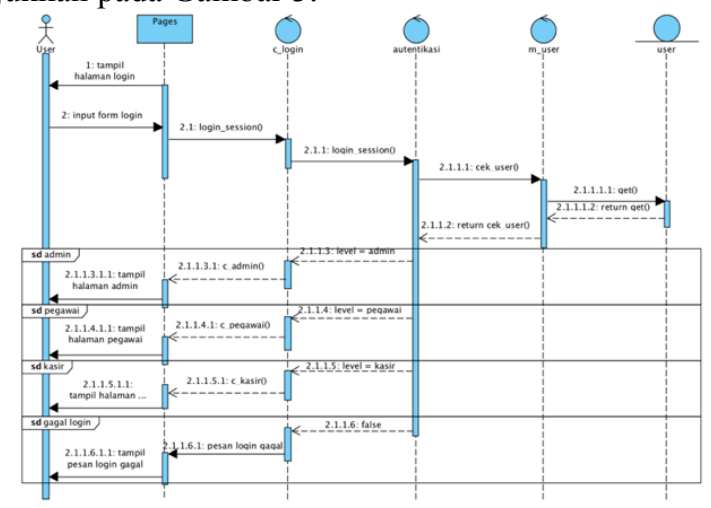

Gambar 3. Sequence diagram login

Berikut adalah sequence diagram add karyawan yang ditunjukkan pada Gambar 4.

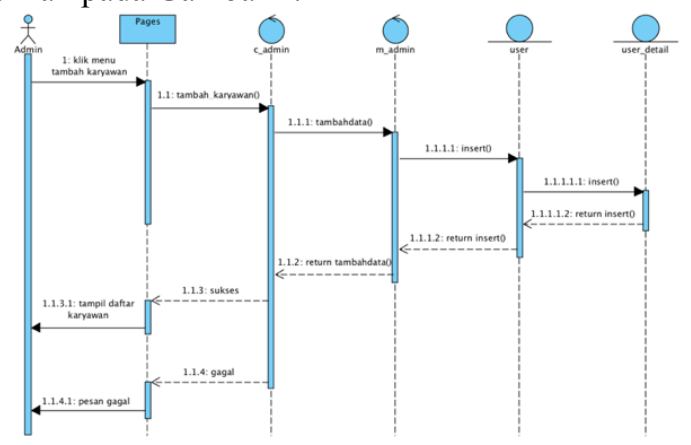

Gambar 4. Sequence diagram add karyawan

Berikut adalah sequence diagram update karyawan yang ditunjukkan pada Gambar 5.

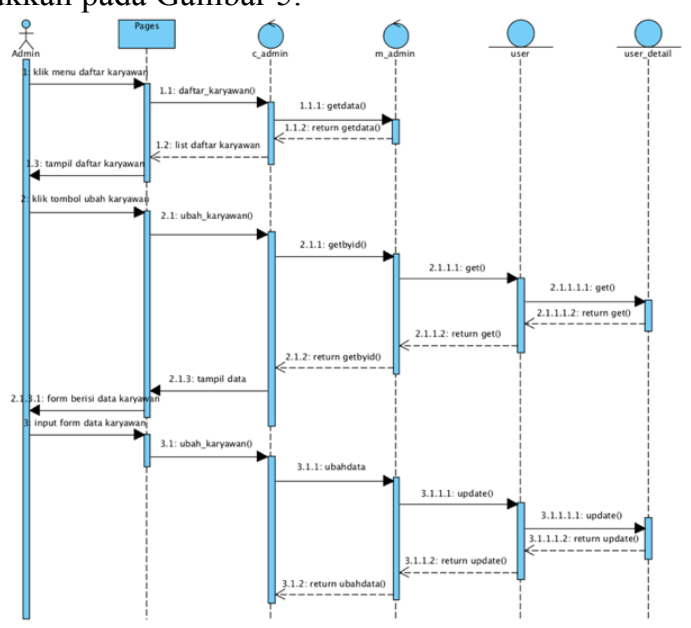

Gambar 5. Sequence diagram update karyawan

Berikut adalah sequence diagram delete karyawan yang ditunjukkan pada Gambar 6.

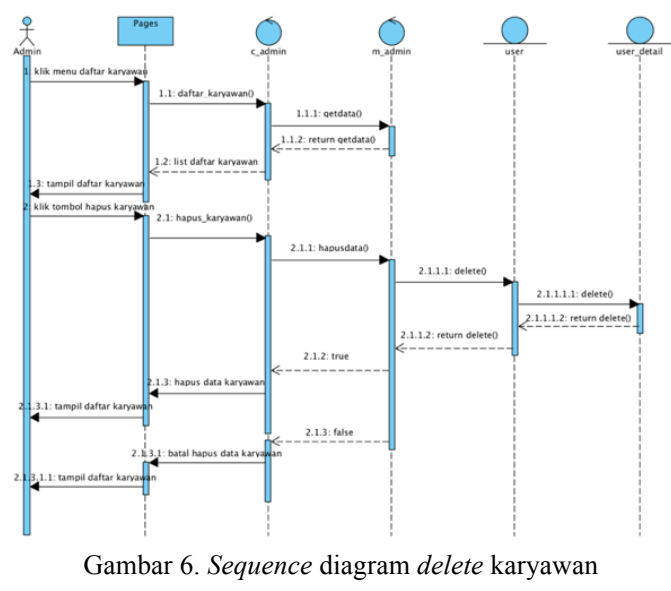

Berikut adalah sequence diagram melihat daftar karyawan yang ditunjukkan pada Gambar 7.

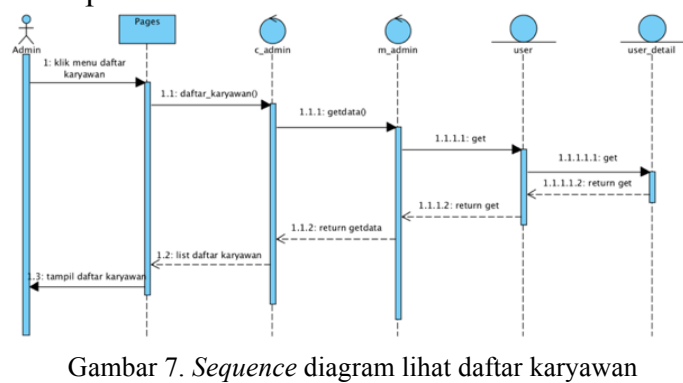

Berikut adalah sequence diagram mengubah nama toko yang ditunjukkan pada Gambar 8.

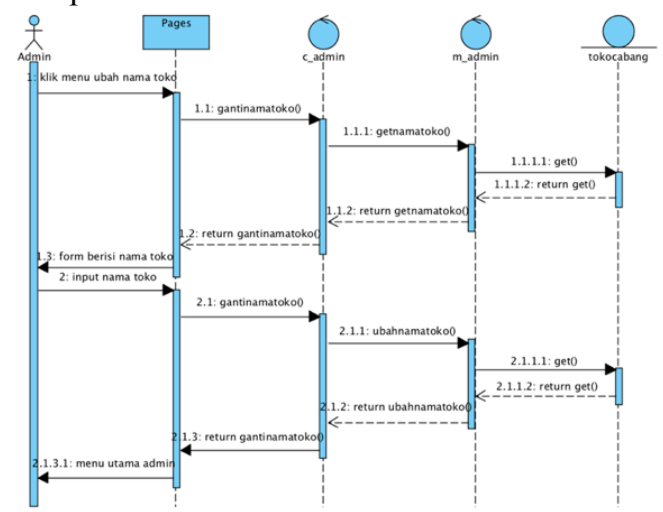

Gambar 8. Sequence diagram ubah nama toko

Berikut adalah sequence diagram add produk yang ditunjukkan pada Gambar 9.

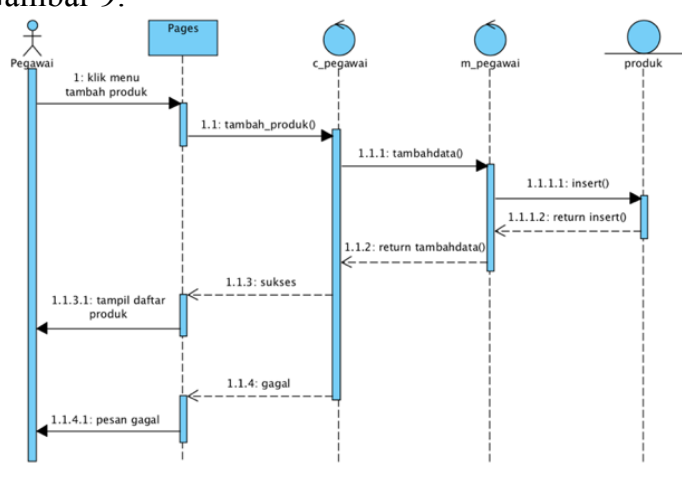

Gambar 9. Sequence diagram add produk

Berikut adalah sequence diagram update produk yang ditunjukkan pada Gambar 10. 


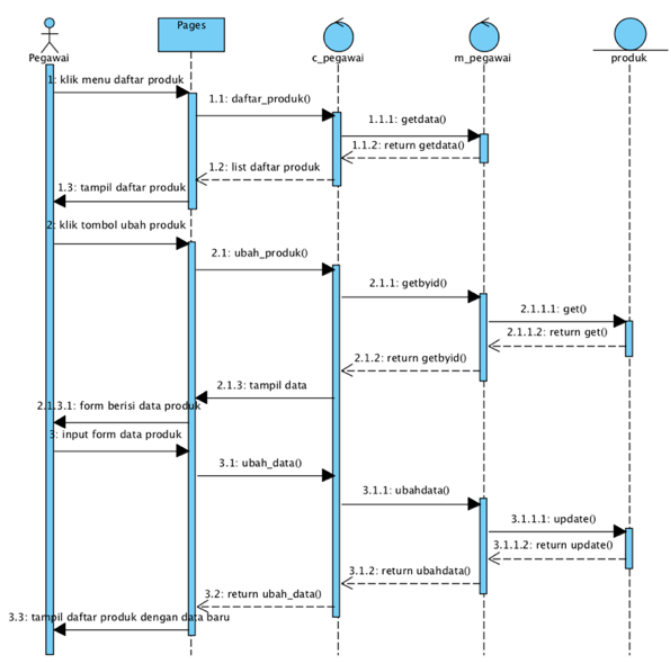

Gambar 10. Sequence diagram update produk

Berikut adalah sequence diagram delete produk yang ditunjukkan pada Gambar 11.

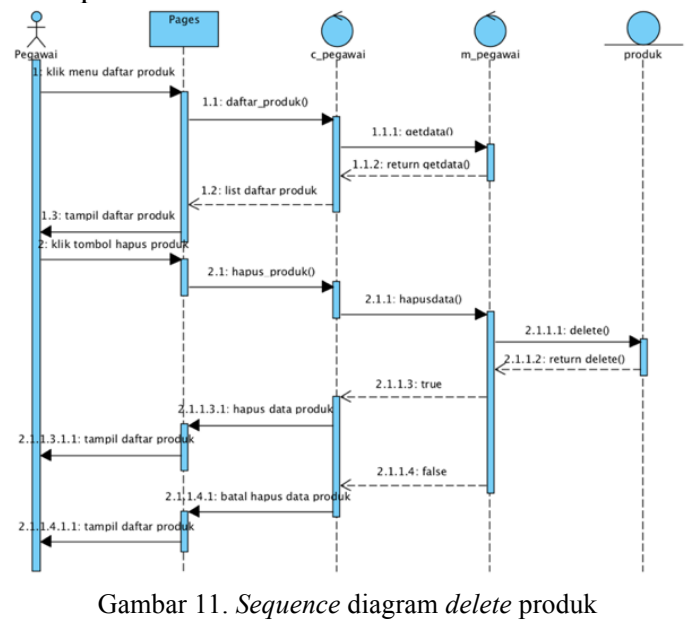

Berikut adalah sequence diagram lihat daftar produk yang ditunjukkan pada Gambar 12.

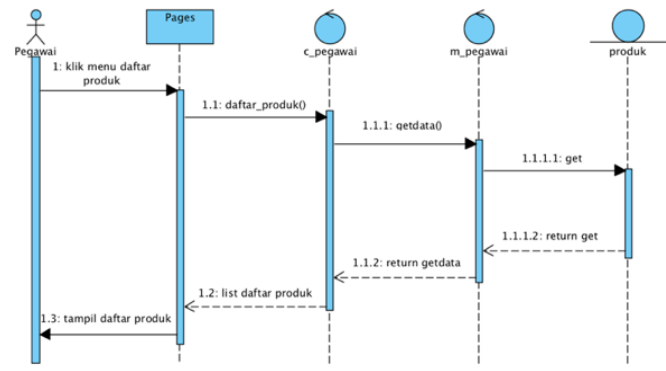

Gambar 12. Sequence diagram lihat daftar produk

Berikut adalah sequence diagram lihat srok produk yang ditunjukkan pada Gamabr 13.

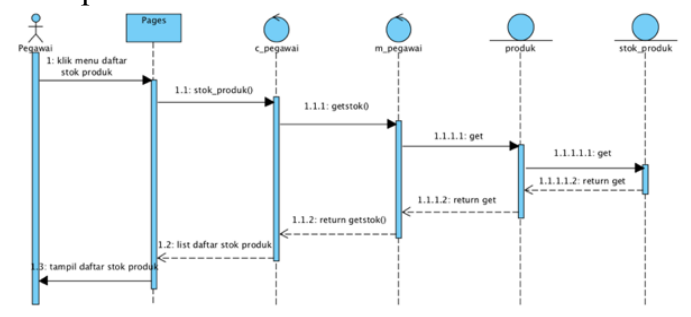

Gambar 13. Sequence diagram lihat stok produk

Berikut adalah sequence diagram add stok yang ditunjukkan pada gambar Gambar 14.

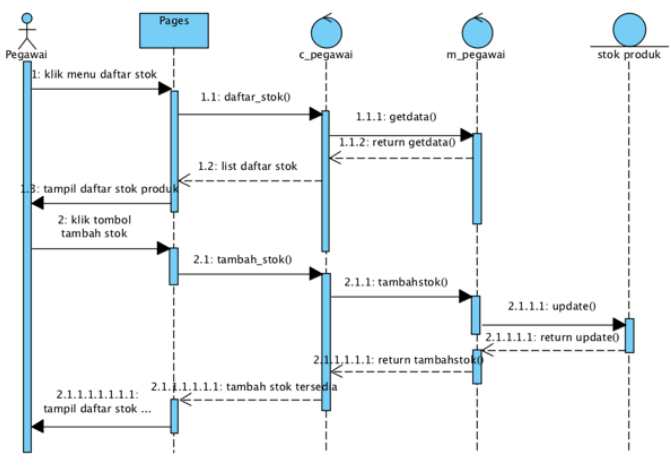

Gambar 14. Sequence diagram add stok

Berikut adalah sequence diagram melihat data barang masuk dan data transaksi (barang keluar)yang ditunjukkan pada Gambar 15.

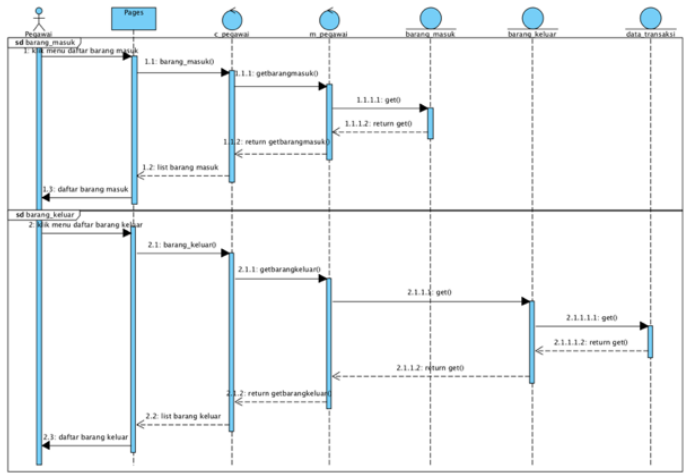

Gambar 15. Sequence diagram lihat data barang masuk dan data transaksi (barang keluar)

Berikut adalah sequence diagram pesan produk ke distributor yang ditunjukkan pada Gambar 16.

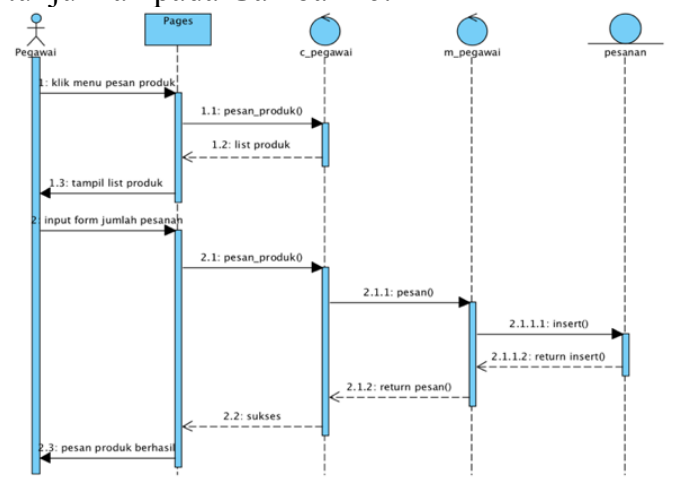

Gambar 16. Sequence diagram pesan produk ke distributor

Berikut adalah sequence diagram melihat status pesanan yang ditunjukkan pada Gambar 17.

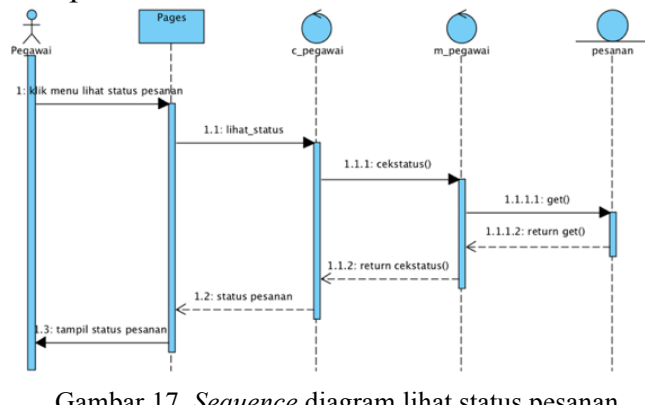

Berikut adalah sequence diagram mendata pembelian yang ditunjukkan pada Gambar 18. 


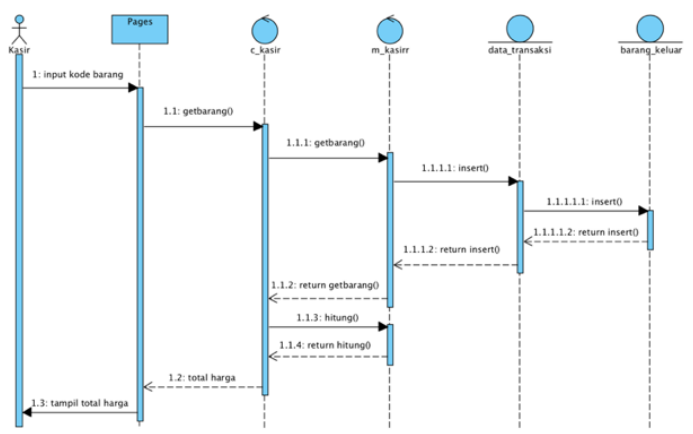

Gambar 18. Sequence diagram mendata barang pembelian

Class diagram menggambarkan struktur dan deskripsi class, package, dan objek beserta hubungan satu sama lain seperti containment, pewarisan, asosiasi, dan lain-ain. Class diagram berfungsi untuk menjelaskan tipe dari objek sistem dan hubungannya dengan objek yang lain. Objek adalah nilai tertentu dari setiap attribute kelas entity. Berikut kelas diagram dari sistem point of sale toko Torani yang akan dibangun seperti ditunjukkan pada Gambar 19.

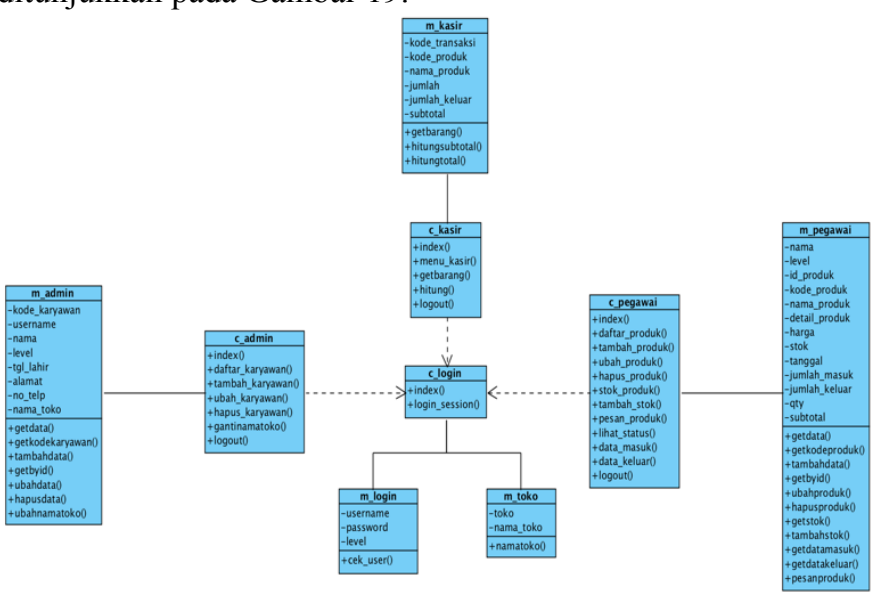

Gambar 19. Class diagram

Setelah perancangan perangkat lunak selesai dibuat, langkah selanjutnya adalah merancang basis data yang akan digunakan untuk menyimpan seluruh data yang akan digunakan oleh sistem.

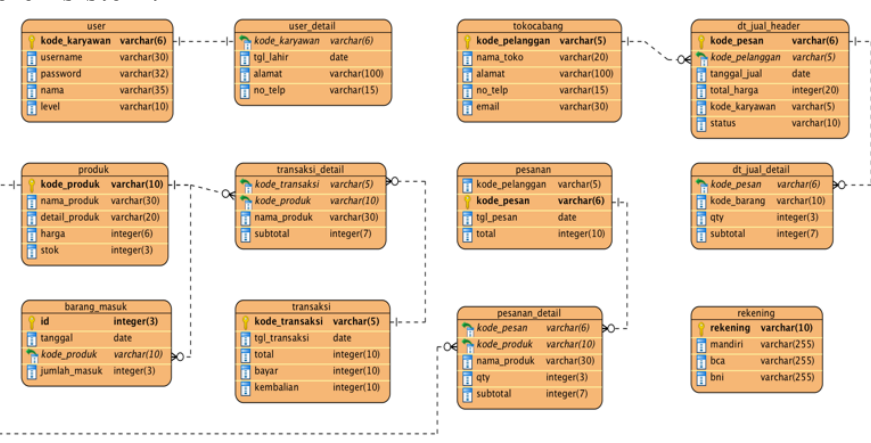

Gambar 20. Entity Relationship Diagram rancangan basis data

Dari Entity Relationship Diagram yang ditunjukkan pada Gambar 20 di atas, dapat diperoleh rancangan basis data dari class-class yang ada. Basis data yang digambarkan di atas telah melalui proses normalisasi sehingga dapat mengatasi terjadinya redudansi dan duplikasi data. ${ }^{[5]}$

Pembuatan basis data dilakukan menggunakan bahasa SQL (Structure Query Language), dimana basis data atau DBMS (Database Management System) yang digunakan adalah MySQL. Berikut adalah struktur dari tabel-tabel yang diimplementasikan dalam basis data sesuai dengan rancangan sebelumnya.
Struktur dari tabel user dijelaskan pada Tabel 3.

Tabel 3. Struktur tabel user

\begin{tabular}{|c|c|l|}
\hline Field & \multicolumn{1}{|c|}{ Jenis } & \multicolumn{1}{|c|}{ Keterangan } \\
\hline kode_karyawan & varchar(6) & Primary key \\
\hline username & varchar(30) & $\begin{array}{l}\text { Username yang } \\
\text { digunakan untuk } \\
\text { login ke sistem }\end{array}$ \\
\hline password & varchar(32) & - \\
\hline nama & varchar(35) & - \\
\hline level & $\begin{array}{c}\text { enum('Admin', } \\
\text { 'Pegawai', } \\
\text { 'Kasir') }\end{array}$ & Level user \\
\hline
\end{tabular}

Struktur dari tabel user_detail dijelaskan pada Tabel 4.

Tabel 4. Struktur tabel user detail

\begin{tabular}{|c|c|l|}
\hline \multicolumn{1}{|c|}{ Field } & \multicolumn{1}{|c|}{ Jenis } & \multicolumn{1}{c|}{ Keterangan } \\
\hline kode_karyawan & varchar(6) & $\begin{array}{l}\text { Foreign key yang } \\
\text { terhubung dengan } \\
\text { tabel user }\end{array}$ \\
\hline tgl_lahir & Date & $\begin{array}{l}\text { Tanggal lahir } \\
\text { menggunakan } \\
\text { format tanggal }\end{array}$ \\
\hline alamat & varchar(100) & - \\
\hline no_telp & varchar(15) & - \\
\hline
\end{tabular}

Struktur dari tabel tokocabang dijelaskan pada Tabel 5.

Tabel 5. Struktur tabel tokocabang

\begin{tabular}{|c|c|l|}
\hline Field & Jenis & \multicolumn{1}{|c|}{ Keterangan } \\
\hline kode_pelanggan & varchar(6) & Primary key \\
\hline nama_toko & $\operatorname{varchar}(20)$ & - \\
\hline alamat & varchar(100) & - \\
\hline no_telp & varchar(15) & - \\
\hline email & varchar(30) & - \\
\hline
\end{tabular}

Struktur dari tabel produk dijelaskan pada Tabel 6 .

Tabel 6. Struktur tabel produk

\begin{tabular}{|c|c|l|}
\hline Field & Jenis & \multicolumn{1}{|c|}{ Keterangan } \\
\hline kode_produk & varchar(10) & Primary key \\
\hline nama_produk & varchar(30) & - \\
\hline detail_produk & varchar(20) & - \\
\hline harga & $\operatorname{int}(6)$ & - \\
\hline stok & $\operatorname{int}(3)$ & - \\
\hline
\end{tabular}

Struktur dari tabel barang_masuk dijelaskan pada Tabel 7. Tabel 7. Struktur tabel barang masuk

\begin{tabular}{|c|c|l|}
\hline Field & Jenis & \multicolumn{1}{|c|}{ Keterangan } \\
\hline id & int(3) & Primary key \\
\hline tanggal & date & - \\
\hline kode_produk & varchar(10) & $\begin{array}{l}\text { Foreign key yang } \\
\text { menghubungkan } \\
\text { dengan tabel } \\
\text { produk }\end{array}$ \\
& & - \\
\hline jumlah_masuk & $\operatorname{int}(3)$ & \\
\hline
\end{tabular}

Struktur dari tabel transaksi dijelaskan pada Tabel 8.

Tabel 8. Struktur tabel transaksi

\begin{tabular}{|c|c|l|}
\hline Field & Jenis & \multicolumn{1}{|c|}{ Keterangan } \\
\hline kode_transaksi & varchar(5) & Primary key \\
\hline tgl_transaksi & date & - \\
\hline total & $\operatorname{int}(10)$ & - \\
\hline bayar & $\operatorname{int}(10)$ & - \\
\hline kembalian & $\operatorname{int}(10)$ & - \\
\hline
\end{tabular}


Struktur dari tabel transaksi detail dijelaskan pada Tabel 9.

Tabel 9. Struktur tabel transaksi_detail

\begin{tabular}{|c|c|l|}
\hline Field & \multicolumn{1}{|c|}{ Jenis } & \multicolumn{1}{|c|}{ Keterangan } \\
\hline kode_transaksi & varchar(5) & $\begin{array}{l}\text { Foreign key yang } \\
\text { menghubungkan } \\
\text { dengan tabel } \\
\text { transaksi }\end{array}$ \\
\hline kode_produk & varchar(10) & $\begin{array}{l}\text { Foreign key yang } \\
\text { menghubungkan } \\
\text { dengan tabel } \\
\text { produk }\end{array}$ \\
\hline nama_produk & varchar(30) & - \\
\hline subtotal & $\operatorname{int}(7)$ & - \\
\hline
\end{tabular}

Struktur dari tabel pesanan dijelaskan pada Tabel 10.

Tabel 10. Struktur tabel pesanan

\begin{tabular}{|c|c|l|}
\hline Field & Jenis & \multicolumn{1}{|c|}{ Keterangan } \\
\hline kode_pelanggan & varchar(5) & - \\
\hline kode_pesan & varchar(6) & Primary key \\
\hline tgl_pesan & date & - \\
\hline total & int $(10)$ & - \\
\hline
\end{tabular}

Struktur dari tabel pesanan_detail dijelaskan pada Tabel 11.

Tabel 11. Struktur tabel pesanan_detail

\begin{tabular}{|c|c|l|}
\hline Field & Jenis & \multicolumn{1}{|c|}{ Keterangan } \\
\hline kode_pesan & varchar(6) & $\begin{array}{l}\text { Foreign key yang } \\
\text { menghubungkan } \\
\text { dengan tabel } \\
\text { pesanan }\end{array}$ \\
\hline kode_produk & varchar(10) & $\begin{array}{l}\text { Foreign key yang } \\
\text { menghubungkan } \\
\text { dengan tabel } \\
\text { produk }\end{array}$ \\
& & - \\
\hline nama_produk & varchar(30) & - \\
\hline qty & $\operatorname{int}(10)$ & - \\
\hline subtotal & $\operatorname{int}(10)$ & \\
\hline
\end{tabular}

Struktur dari tabel dt jual header dijelaskan pada Tabel 12 .

Tabel 12. Struktur tabel dt jual header

\begin{tabular}{|c|c|l|}
\hline Field & Jenis & \multicolumn{1}{|c|}{ Keterangan } \\
\hline kode_pesan & varchar(6) & Primary key \\
\hline kode_pelanggan & varchar(10) & $\begin{array}{l}\text { Foreign key yang } \\
\text { menghubungkan } \\
\text { dengan tabel } \\
\text { tokocabang }\end{array}$ \\
\hline tanggal_jual & date & - \\
\hline total_harga & int(20) & - \\
\hline kode_karyawan & varchar(5) & $\begin{array}{l}\text { Merupakan field } \\
\text { yang hanya dapat } \\
\text { diisi oleh pihak } \\
\text { distributor }\end{array}$ \\
\hline status & $\begin{array}{c}\text { enum('PENDING', } \\
\text { 'DIPROSES, } \\
\text { 'DITERIMA', } \\
\text { pesanan dari barang }\end{array}$ \\
& BELI & \\
\hline & DITEMPAT') & \\
\hline
\end{tabular}

Struktur dari tabel dt_jual_detail dijelaskan pada Tabel 13.

Tabel 13. Struktur tabel dt jual_detail

\begin{tabular}{|c|c|l|}
\hline Field & Jenis & \multicolumn{1}{|c|}{ Keterangan } \\
\hline kode_pesan & varchar(6) & Primary key \\
\hline kode_barang & $\operatorname{varchar}(10)$ & - \\
\hline qty & $\operatorname{int}(3)$ & - \\
\hline subtotal & $\operatorname{int}(7)$ & - \\
\hline
\end{tabular}

Struktur dari tabel dt rekeing dijelaskan pada Tabel 14

Tabel 14. Struktur tabel dt_rekening

\begin{tabular}{|c|c|l|}
\hline Field & Jenis & \multicolumn{1}{|c|}{ Keterangan } \\
\hline rekening & varchar $(10)$ & Primary key \\
\hline mandiri & text & - \\
\hline bca & text & - \\
\hline bni & text & - \\
\hline
\end{tabular}

Setelah database selesai dibentuk, langkah selanjutnya yaitu implementasi program. Pada implementasi program, dibagi menurut kategori dan fungsi sesuai rancangan sebelumnya. Dalam pengimplementasian desain user interface serta pengambilan data dalam database, digunakan model dan controller yang menampung variabel maupun method yang bersifat public sehingga dapat digunakan di seluruh class dan kemudian hasilnya ditampilkan oleh module view. ${ }^{[3]}$

Langkah pertama yang dilakukan adalah membuat autentikasi login. Autentikasi dibuat untuk pengenalan user dengan aplikasi, apabila user dikenali, maka user tersebut dapat mengakses aplikasi sesuai dengan rolenya.

Pustaka autentikasi menggunakan sebuah tabel di dalam database. Tabel yang digunakan adalah tabel user. Pustaka ini juga menggunakan sebuah model untuk melakukan interaksi data dengan database. Berikut adalah potongan kode dari fungsi login() yang berfungsi untuk melakukan autentikasi login pada aplikasi ditunjukkan pada Gambar 33.

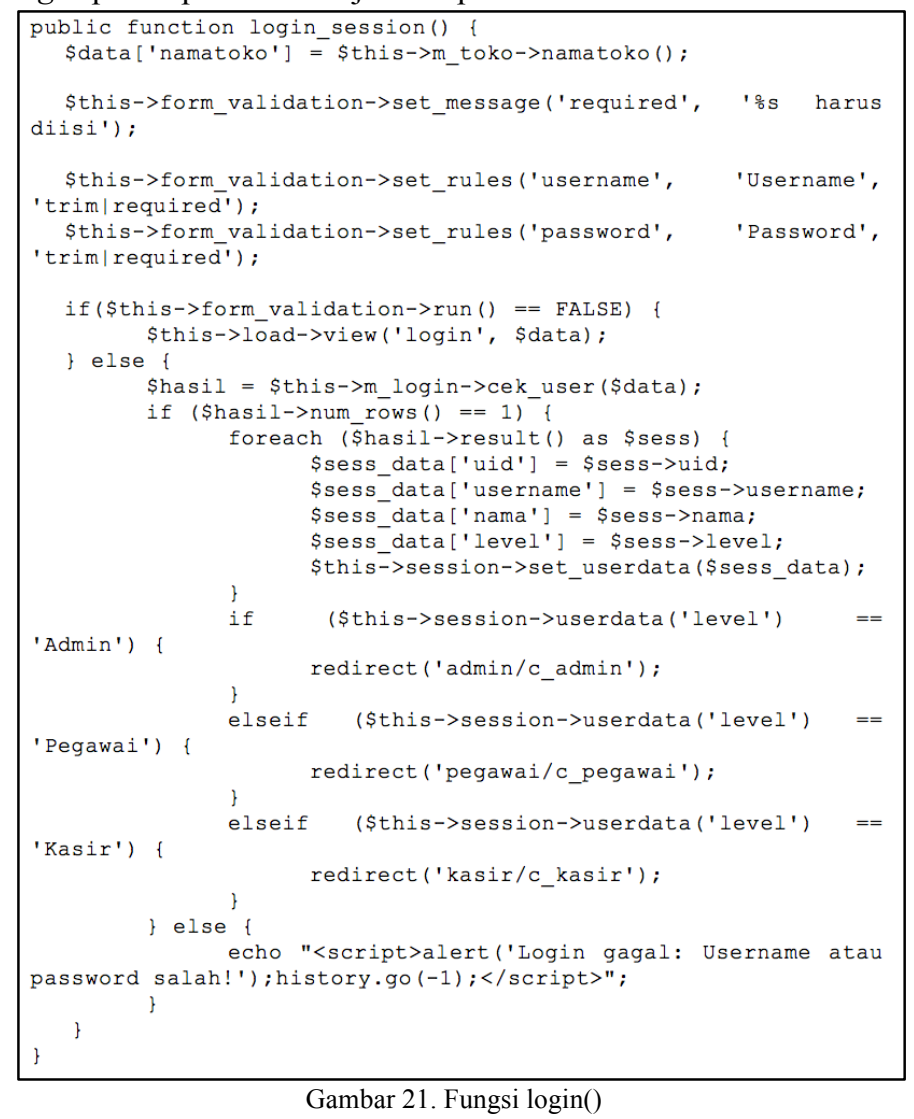

Berikut adalah potongan kode dari fungsi cek user() yang berfungsi untuk mengecek username dan password di dalam database ditunjukkan pada Gambar 34.

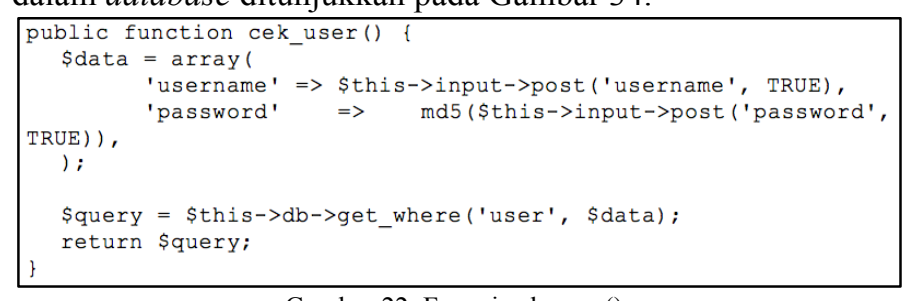

Gambar 22. Fungsi cek_user()

JTsiskom - 450 
Berikut adalah potongan kode dari fungsi logout() yang berfungsi untuk dan mengakhiri session login dan keluar dari aplikasi ditunjukkan pada Gambar 35.

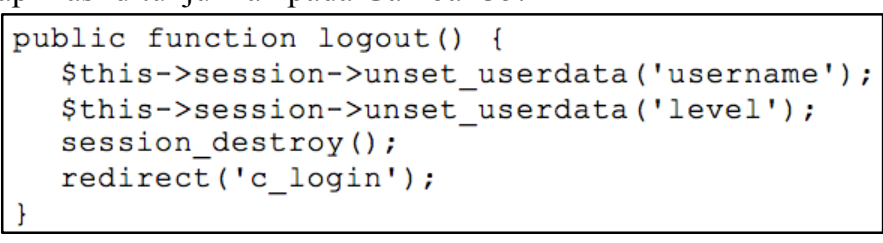

Gambar 23. Fungsi logout()

Selanjutnya adalah membuat halaman login yang merupakan halaman awal untuk masuk ke dalam aplikasi seperti yang digambarkan pada Gambar 36.

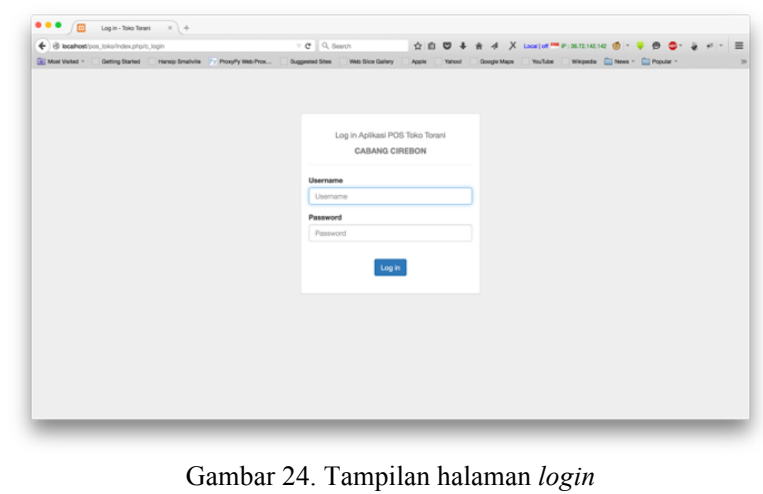

Selanjutnya membuat halaman utama yang merupakan halaman yang pertama ditampilkan setelah login seperti yang digambarkan pada Gambar 37.

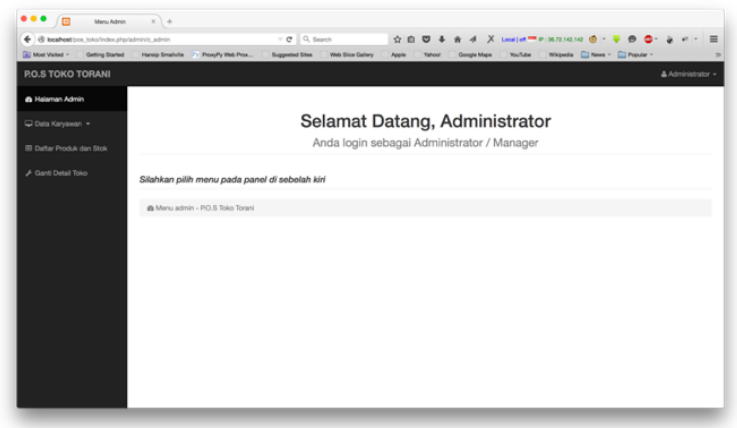

Gambar 25. Tampilan halaman utama

Selanjutnya membuat halaman daftar karyawan yang merupkaan halaman yang berfungsi untuk menampilkan seluruh data karyawan seperti yang digambarkan pada Gambar 38.

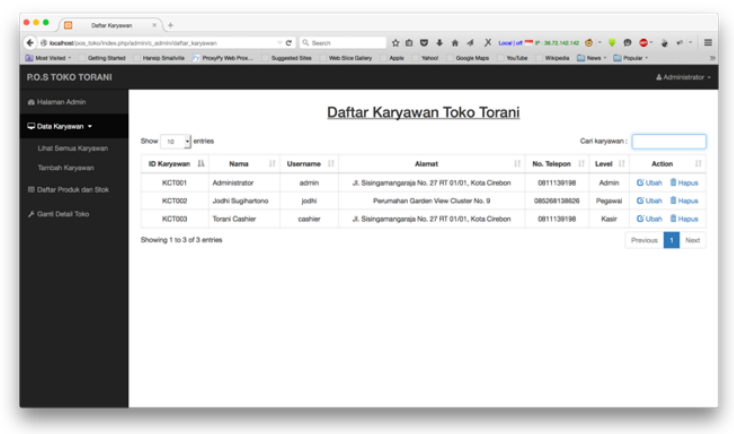

Gambar 26. Tampilan halaman daftar karyawan

Selanjutnya membuat halaman tambah karyawan yang merupakan halaman untuk menambah karyawan baru seperti yang digambarkan pada Gambar 39.

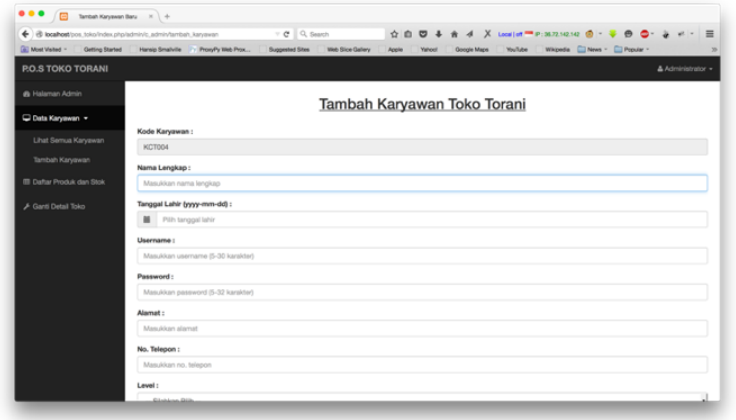

Gambar 27. Halaman tambah karyawan baru

Selanjutnya adalah membuat halaman ubah data karyawan yang merupakan halaman yang berfungsi untuk menampilkan dan mengubah data karyawan seperti yang digambarkan pada Gambar 40.

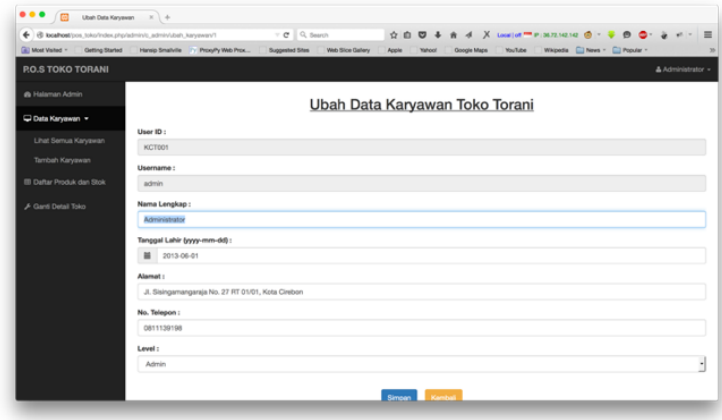

Gambar 28. Halaman ubah data karyawan

Selanjutnya adalah membuat halaman daftar produk dan stok (admin) yang merupakan halaman yang berfungsi untuk menampilkan daftar produk dan stok seperti yang digambarkan pada Gambar 41 .

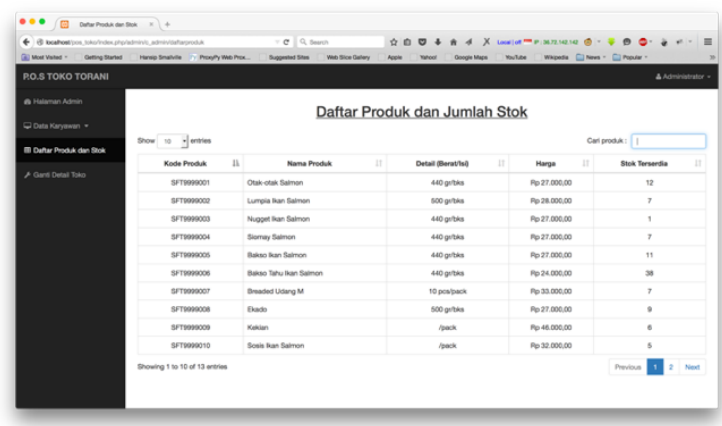

Gambar 29. Halaman daftar produk dan stok

Selanjutnya adalah membuat halaman ubah detail toko yang merupakan halaman untuk mengubah detail toko yang akan digunakan sebagai alamat pengiriman pesanan seperti yang digambarkan pada Gambar 42.

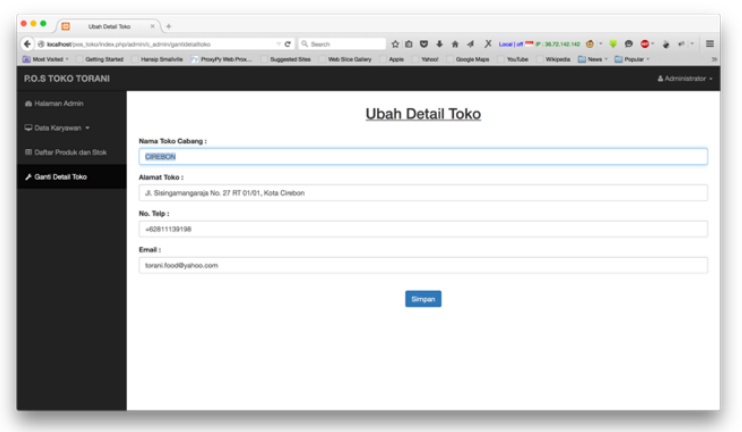

Gambar 30. Halaman ubah detail toko 
Selanjutnya adalah membuat halaman daftar produk dan stok (pegawai) yang merupakan Halaman yang berfungsi untuk menampilkan daftar produk dan stok seperti yang digambarkan pada Gambar 43.

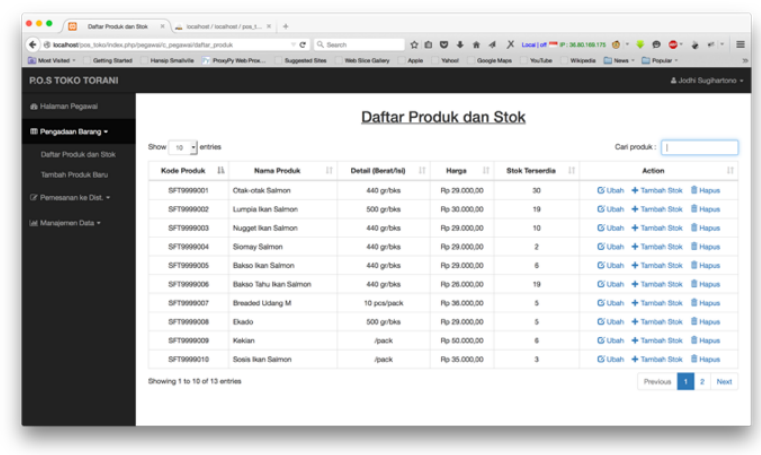

Gambar 31. Halaman daftar produk dan stok

Selanjutnya adalah membuat halaman tambah produk baru yang merupakan halaman untuk menambah produk baru seperti yang digambarkan pada Gambar 44.

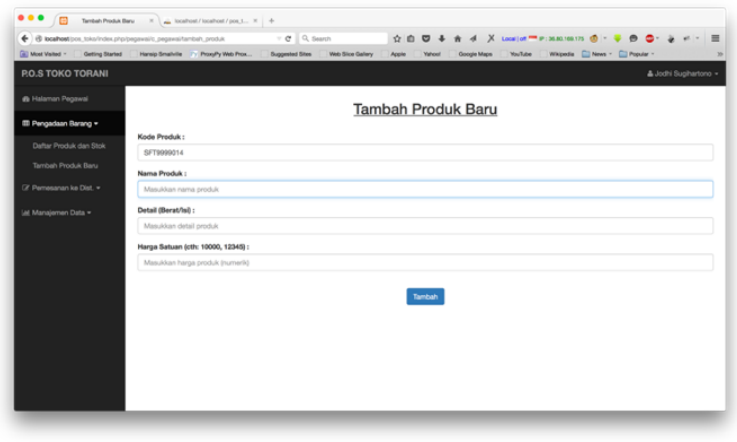

Gambar 32. Halaman tambah produk baru

Selanjutnya adalah Membuat halaman ubah detail produk yang merupakan halaman yang berfungsi untuk menampilkan dan mengubah detail produk seperti yang digambarkan pada Gambar 45.

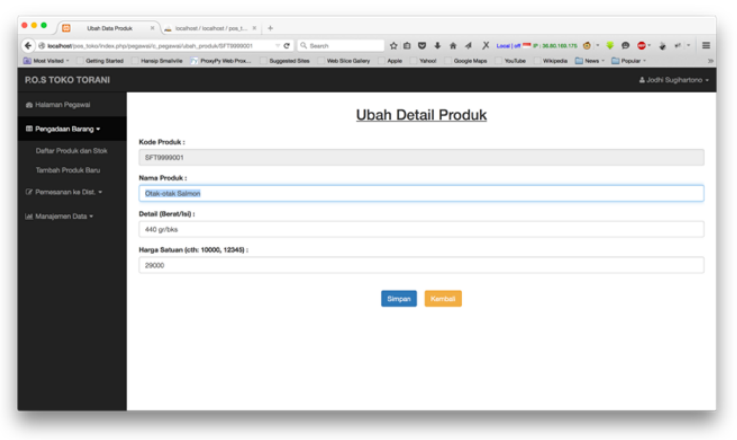

Gambar 33. Halaman ubah detail produk

Selanjutnya adalah membuat halaman tambah stok yan merupakan halaman untuk menambah jumlah stok produk seperti yang digambarkan pada Gambar 46.

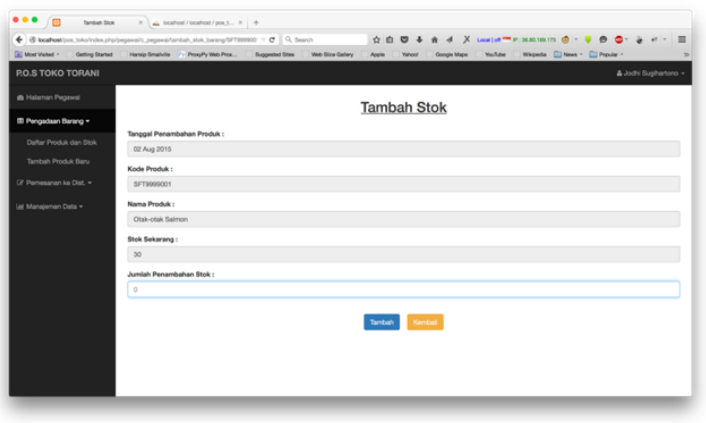

Selanjutnya adalah membuat halaman pesan produk ke distributor yang berfungsi untuk melakukan pemesanan produk kepada distributor dan terhubung langsung dengan database distributor seperti yang digambarkan pada Gambar 47.

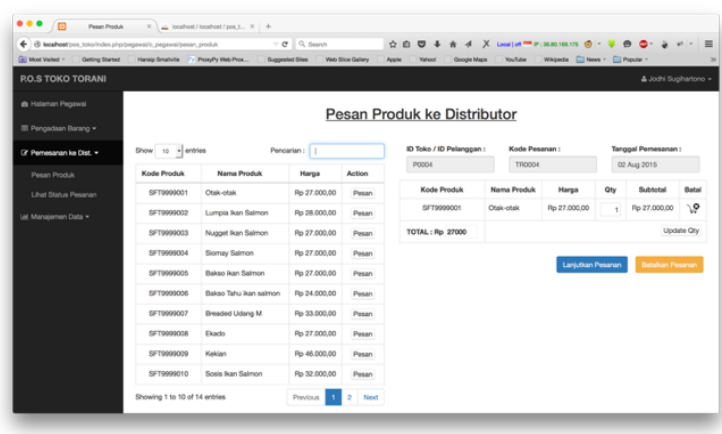

Gambar 35. Halaman pesan produk

Selanjutnya adalah membuat halaman selesai pesan yang merupakan halaman yang berisi daftar rekening untuk pembayaran yang tersimpan di dalam database distributor seperti yang digambarkan pada Gambar 48.

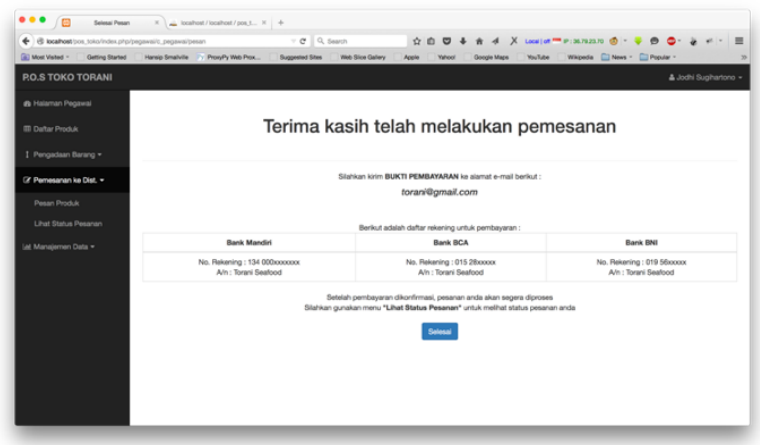

Gambar 36. Halaman selesai pesan

Selanjutnya adalah membuat halaman lihat status pesanan yang merupakan halaman untuk melihat status pesanan yang sedang berjalan seperti yang digambarkan pada Gambar 49.

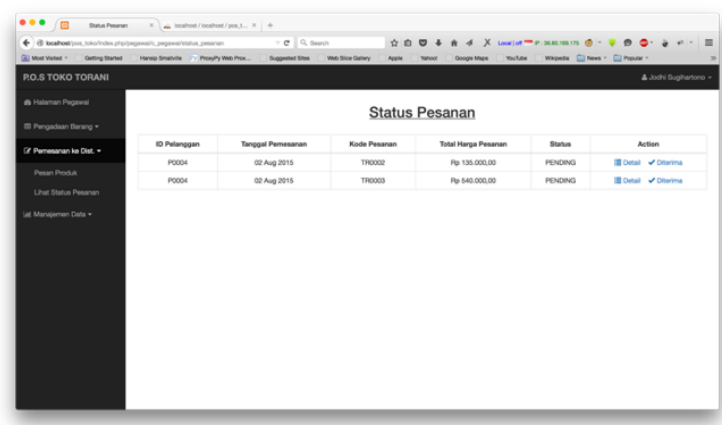

Gambar 37. Halaman lihat status pesanan

Selanjutnya adalah membuat halaman detail pesanan yang merupakan halaman untuk melihat detail pesanan yang sedang berlangsung seperti yang digambarkan pada Gambar 50 . 


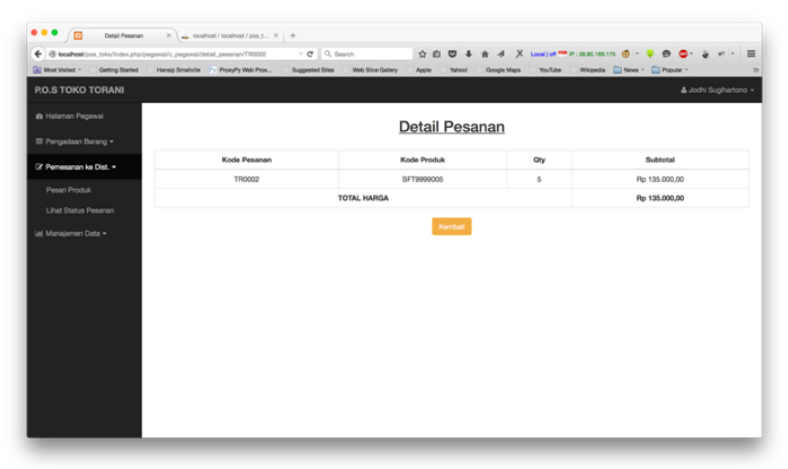

Gambar 38. Halaman detail pesanan

Selanjutnya adalah membuat halaman data barang masuk yang merupakan halaman untuk melihat daftar dan jumlah barang masuk seperti yang digambarkan pada Gambar 51.

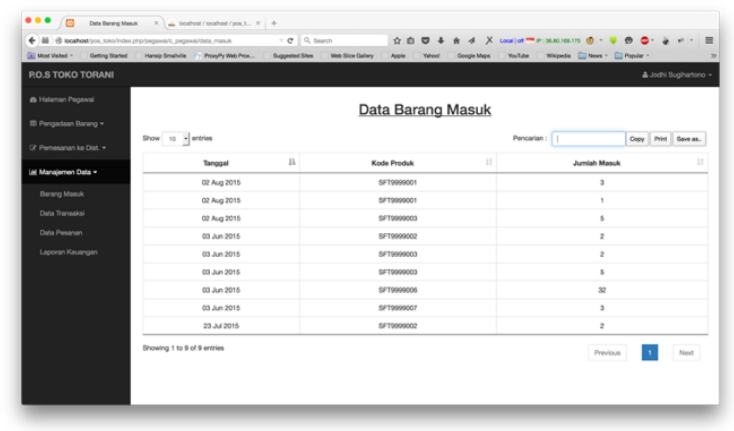

Gambar 39. Halaman data barang masuk

Selanjutnya adalah membuat halaman data transaksi yang merupakan halaman untuk melihat data transaksi yang pernah dilakukan oleh kasir seperti yang digambarkan pada Gambar 52.

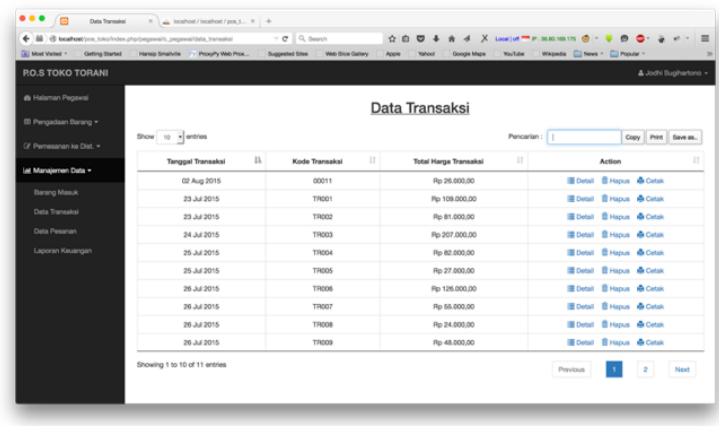

Gambar 40. Halaman data transaksi

Selanjutnya adalah membuat halaman detail transaksi yang merupakan halaman untuk melihat detail transaksi tertentu seperti yang digambarkan pada Gambar 53.

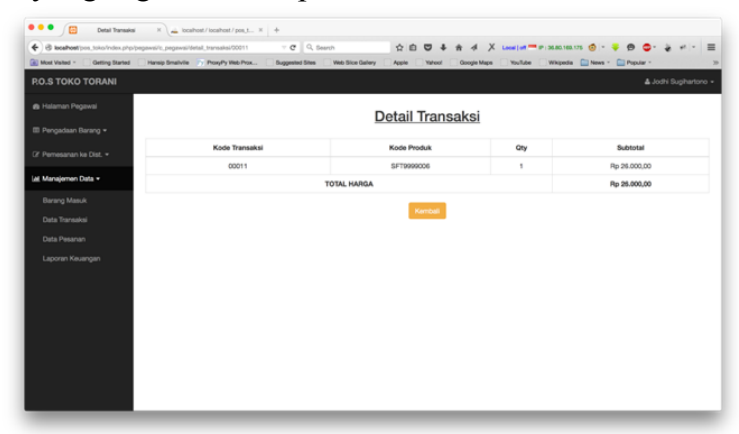

Gambar 41. Halaman detail transaksi
Selanjutnya adalah Membuat halaman data pesanan yang merupakan halaman untuk melihat seluruh data pesanan yang pernah dilakukan seperti yang digambarkan pada Gambar 54.

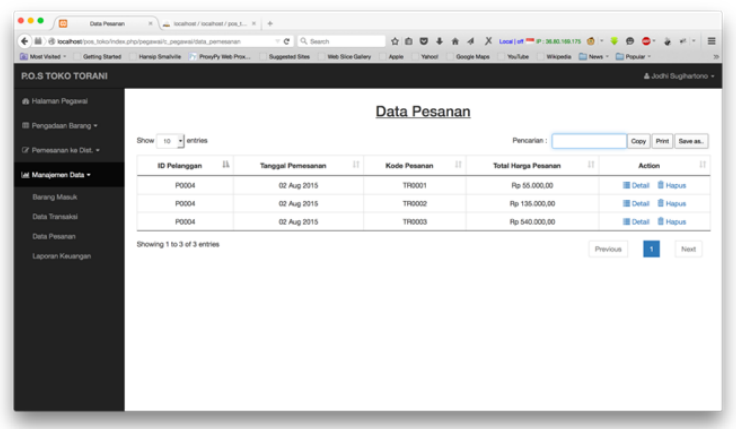

Gambar 42. Halaman data pesanan

Selanjutnya adalah membuat halaman detail pesanan yang merupakan halaman untuk melihat detail pesanan tertentu seperti yang digambarkan pada Gambar 55 .

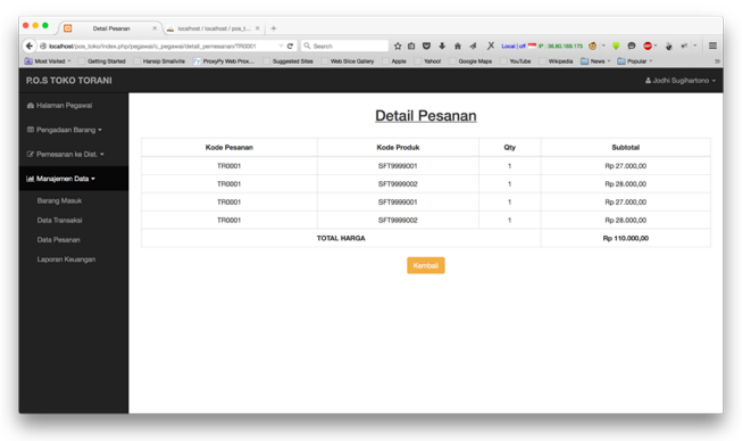

Gambar 43. Halaman detail pesanan

Selanjutnya adalah membuat halaman laporan keuangan yang merupakan alaman untuk melihat jumlah pemasukan dan pengeluaran berdasarkan tanggal atau bulan tertentu seperti yang digambarkan pada Gambar 56.

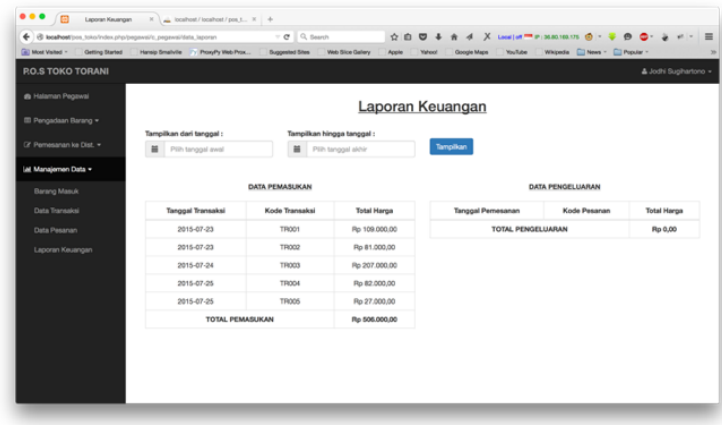

Gambar 44. Halaman laporan keuangan

Selanjutnya adalah membuat halaman menu kasir yang merupakan halaman utama kasir untuk melakukan transaksi jual beli seperti yang digambarkan pada Gambar 57.

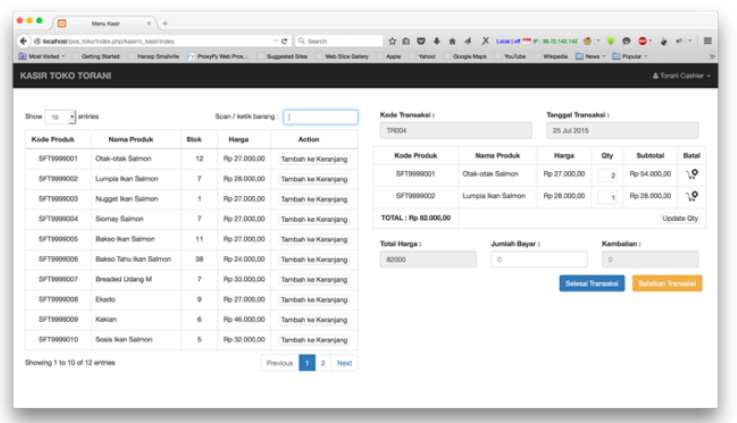


Selanjutnya adalah membuat halaman billing info yang merupakan halaman untuk menyimpan data transaksi dan untuk mencetak bukti transaksi seperti yang digambarkan pada Gambar 58.

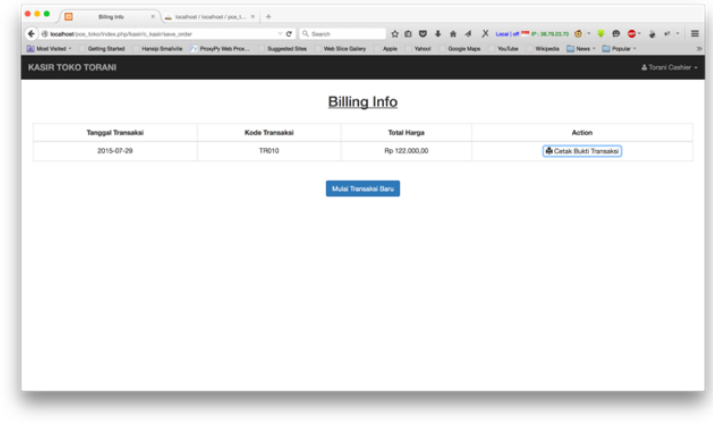

Gambar 46. Halaman billing info

Selanjutnya adalah membuat halaman cetak bukti transaksi yang merupakan halaman berbentuk print preview dari bukti transaksi yang siap cetak seperti yang digambarkan pada Gambar 59.

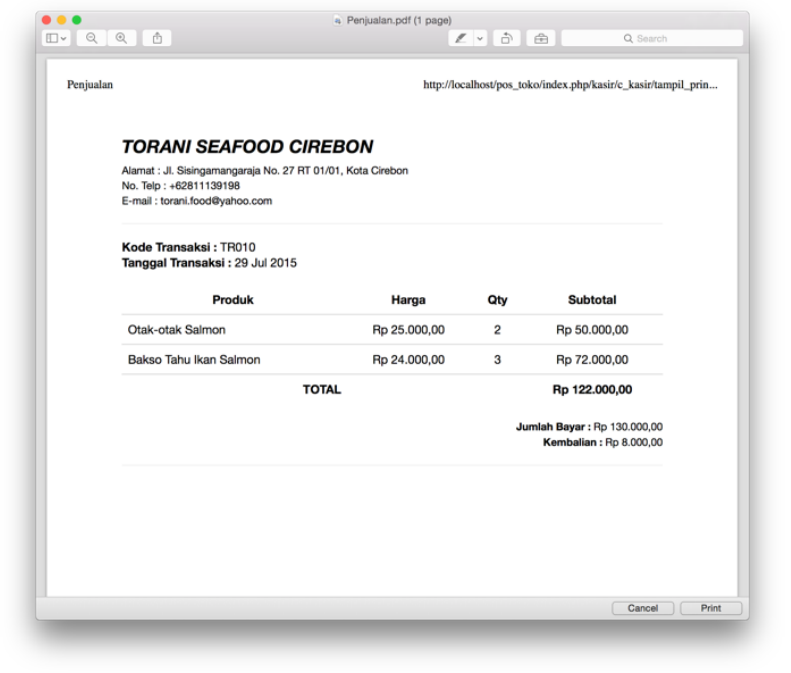

Gambar 47. Halaman cetak bukti transaksi

Proses pengujian dilakukan dengan menggunakan metode black box. Metode black box menguji aplikasi dengan berfokus pada spesifikasi fungsional dari perangkat lunak. Bentuk pengujian dilakukan dengan memeriksa kondisi input dan melakukan pengetesan pada spesifikasi fungsional dengan langsung menggunakan aplikasi.

Tabel 15. Tabel pengujian

\begin{tabular}{|c|c|c|c|}
\hline $\begin{array}{c}\text { Nama } \\
\text { Pengujian } \\
\end{array}$ & $\begin{array}{c}\text { Bentuk } \\
\text { Pengujian } \\
\end{array}$ & $\begin{array}{c}\text { Hasil Yang } \\
\text { Diharapkan }\end{array}$ & $\begin{array}{c}\text { Hasil } \\
\text { Pengujian }\end{array}$ \\
\hline $\begin{array}{l}\text { Pengujian } \\
\text { login sukses } \\
\text { sebagai } \\
\text { admin }\end{array}$ & $\begin{array}{l}\text { Mengisi field } \\
\text { username dan } \\
\text { password yang } \\
\text { sudah terdaftar } \\
\text { sebagai admin }\end{array}$ & $\begin{array}{l}\text { Masuk ke menu } \\
\text { utama admin } \\
\text { dengan } \\
\text { tampilan menu } \\
\text { admin } \\
\end{array}$ & Berhasil \\
\hline $\begin{array}{l}\text { Pengujian } \\
\text { login sukses } \\
\text { sebagai } \\
\text { pegawai }\end{array}$ & $\begin{array}{c}\text { Mengisi field } \\
\text { username dan } \\
\text { password yang } \\
\text { sudah terdaftar } \\
\text { sebagai pegawai }\end{array}$ & $\begin{array}{c}\text { Masuk ke menu } \\
\text { utama admin } \\
\text { dengan } \\
\text { tampilan menu } \\
\text { pegawai }\end{array}$ & Berhasil \\
\hline $\begin{array}{c}\text { Pengujian } \\
\text { login sukses } \\
\text { sebagai kasir }\end{array}$ & $\begin{array}{l}\text { Mengisi field } \\
\text { username dan } \\
\text { password yang } \\
\text { sudah terdaftar } \\
\text { sebagai kasir }\end{array}$ & $\begin{array}{l}\text { Masuk ke menu } \\
\text { utama admin } \\
\text { dengan } \\
\text { tampilan menu } \\
\text { kasir }\end{array}$ & Berhasil \\
\hline $\begin{array}{l}\text { Pengujian } \\
\text { login gagal }\end{array}$ & $\begin{array}{l}\text { Mengisi field } \\
\text { dan username } \\
\text { dan password } \\
\text { yang tidak } \\
\text { terdaftar }\end{array}$ & $\begin{array}{c}\text { Menampilkan } \\
\text { pemberitahuan } \\
\text { login gagal }\end{array}$ & Berhasil \\
\hline
\end{tabular}

\begin{tabular}{|c|c|c|c|}
\hline $\begin{array}{l}\text { Pengujian } \\
\text { login salah }\end{array}$ & $\begin{array}{l}\text { Mengosongkan } \\
\text { field username } \\
\text { atau password }\end{array}$ & $\begin{array}{l}\text { Menampilkan } \\
\text { pemberitahuan } \\
\text { bahwa } \\
\text { pengisian field } \\
\text { tidak memenuhi } \\
\text { ketentuan }\end{array}$ & Berhasil \\
\hline $\begin{array}{l}\text { Pengujian } \\
\text { logout } \\
\text { aplikasi }\end{array}$ & $\begin{array}{l}\text { Memilih menu } \\
\text { dropdown pada } \\
\text { nama user di } \\
\text { pojok kanan atas } \\
\text { dan pilih logout }\end{array}$ & $\begin{array}{c}\text { Keluar dari } \\
\text { aplikasi dan } \\
\text { kembali ke } \\
\text { menu login }\end{array}$ & Berhasil \\
\hline $\begin{array}{l}\text { Pengujian } \\
\text { tampilan } \\
\text { halaman } \\
\text { admin }\end{array}$ & $\begin{array}{l}\text { Memilih menu } \\
\text { halaman admin }\end{array}$ & $\begin{array}{l}\text { Menampilkan } \\
\text { halaman utama } \\
\text { admin }\end{array}$ & Berhasil \\
\hline $\begin{array}{c}\text { Pengujian } \\
\text { membuka } \\
\text { tampilan } \\
\text { daftar } \\
\text { karyawan }\end{array}$ & $\begin{array}{l}\text { Memilih menu } \\
\text { dropdown data } \\
\text { karyawan dan } \\
\text { pilih menu lihat } \\
\text { semua karyawan }\end{array}$ & $\begin{array}{c}\text { Menampilkan } \\
\text { halaman yang } \\
\text { berisi tabel } \\
\text { daftar karyawan }\end{array}$ & Berhasil \\
\hline $\begin{array}{l}\text { Pengujian } \\
\text { membuka } \\
\text { tampilan } \\
\text { tambah } \\
\text { karyawan }\end{array}$ & $\begin{array}{c}\text { Memilih menu } \\
\text { dropdown data } \\
\text { karyawan dan } \\
\text { pilih menu } \\
\text { tambah } \\
\text { karyawan } \\
\end{array}$ & $\begin{array}{c}\text { Menampilkan } \\
\text { halaman yang } \\
\text { berisi form } \\
\text { input untuk } \\
\text { mengisi data } \\
\text { karyawan baru }\end{array}$ & Berhasil \\
\hline $\begin{array}{c}\text { Pengujian } \\
\text { membuka } \\
\text { tampilan } \\
\text { daftar produk } \\
\text { dan stok }\end{array}$ & $\begin{array}{l}\text { Memilih menu } \\
\text { daftar produk } \\
\text { dan stok }\end{array}$ & $\begin{array}{c}\text { Menampilkan } \\
\text { halaman yang } \\
\text { berisi tabel } \\
\text { daftar produk } \\
\text { dan stok yang } \\
\text { tersedia }\end{array}$ & Berhasil \\
\hline $\begin{array}{l}\text { Pengujian } \\
\text { membuka } \\
\text { tampilan } \\
\text { ubah detail } \\
\text { toko } \\
\end{array}$ & $\begin{array}{l}\text { Memilih menu } \\
\text { ganti detail toko }\end{array}$ & $\begin{array}{c}\text { Menampilkan } \\
\text { halaman yang } \\
\text { berisi form } \\
\text { berisi detail } \\
\text { toko }\end{array}$ & Berhasil \\
\hline $\begin{array}{l}\text { Pengujian } \\
\text { tampilan } \\
\text { halaman } \\
\text { pegawai }\end{array}$ & $\begin{array}{l}\text { Memilih menu } \\
\text { halaman } \\
\text { pegawai }\end{array}$ & $\begin{array}{l}\text { Menampilkan } \\
\text { halaman utama } \\
\text { pegawai }\end{array}$ & Berhasil \\
\hline $\begin{array}{c}\text { Pengujian } \\
\text { membuka } \\
\text { tampilan } \\
\text { daftar produk }\end{array}$ & $\begin{array}{l}\text { Memilih menu } \\
\text { daftar produk }\end{array}$ & $\begin{array}{c}\text { Menampilkan } \\
\text { halaman yang } \\
\text { berisi tabel } \\
\text { daftar produk } \\
\text { dan detailnya }\end{array}$ & Berhasil \\
\hline $\begin{array}{c}\text { Pengujian } \\
\text { membuka } \\
\text { tampilan } \\
\text { tambah } \\
\text { produk baru }\end{array}$ & $\begin{array}{l}\text { Memilih menu } \\
\text { dropdown } \\
\text { pengadaan } \\
\text { barang dan pilih } \\
\text { menu tambah } \\
\text { produk baru }\end{array}$ & $\begin{array}{c}\text { Menampilkan } \\
\text { halaman yang } \\
\text { berisi form } \\
\text { input untuk } \\
\text { menambah } \\
\text { produk baru }\end{array}$ & Berhasil \\
\hline $\begin{array}{c}\text { Pengujian } \\
\text { membuka } \\
\text { tampilan } \\
\text { pesan produk } \\
\text { ke distributor }\end{array}$ & $\begin{array}{l}\text { Memilih menu } \\
\text { dropdown } \\
\text { pemesanan ke } \\
\text { distributor dan } \\
\text { pilih menu } \\
\text { pesan produk }\end{array}$ & $\begin{array}{l}\text { Menampilkan } \\
\text { halaman yang } \\
\text { berisi tabel } \\
\text { daftar produk } \\
\text { yang disediakan } \\
\text { distributor } \\
\text { beserta detail } \\
\text { pesanan }\end{array}$ & Berhasil \\
\hline $\begin{array}{l}\text { Pengujian } \\
\text { membuka } \\
\text { tampilan } \\
\text { lihat status } \\
\text { pesanan }\end{array}$ & $\begin{array}{l}\text { Memilih menu } \\
\text { dropdown } \\
\text { pemesanan ke } \\
\text { distributor dan } \\
\text { lihat status } \\
\text { pesanan } \\
\end{array}$ & $\begin{array}{c}\text { Menampilkan } \\
\text { halaman yang } \\
\text { berisi tabel } \\
\text { daftar pesanan } \\
\text { dan status } \\
\text { pesanan }\end{array}$ & Berhasil \\
\hline $\begin{array}{c}\text { Pengujian } \\
\text { membuka } \\
\text { tampilan } \\
\text { barang } \\
\text { masuk } \\
\end{array}$ & $\begin{array}{l}\text { Memilih menu } \\
\text { dropdown } \\
\text { manajemen data } \\
\text { dan pilih menu } \\
\text { barang masuk }\end{array}$ & $\begin{array}{c}\text { Menampilkan } \\
\text { halaman yang } \\
\text { berisi tabel } \\
\text { barang masuk }\end{array}$ & Berhasil \\
\hline
\end{tabular}

JTsiskom - 454 


\begin{tabular}{|c|c|c|c|}
\hline $\begin{array}{l}\text { Pengujian } \\
\text { membuka } \\
\text { tampilan data } \\
\text { transaksi }\end{array}$ & $\begin{array}{c}\text { Memilih menu } \\
\text { dropdown } \\
\text { manajemen data } \\
\text { dan pilih menu } \\
\text { data transaksi }\end{array}$ & $\begin{array}{l}\text { Menampilkan } \\
\text { halaman yang } \\
\text { berisi tabel data } \\
\text { transaksi }\end{array}$ & Berhasil \\
\hline $\begin{array}{l}\text { Pengujian } \\
\text { membuka } \\
\text { tampilan data } \\
\text { pesanan }\end{array}$ & $\begin{array}{l}\text { Memilih menu } \\
\text { dropdown } \\
\text { manajemen data } \\
\text { dan pilih menu } \\
\text { data pesanan }\end{array}$ & $\begin{array}{l}\text { Menampilkan } \\
\text { halaman yang } \\
\text { berisi tabel data } \\
\text { pesanan }\end{array}$ & Berhasil \\
\hline $\begin{array}{l}\text { Pengujian } \\
\text { membuka } \\
\text { tampilan } \\
\text { laporan } \\
\text { keuangan }\end{array}$ & $\begin{array}{c}\text { Memilih menu } \\
\text { dropdown } \\
\text { manajemen data } \\
\text { dan pilih menu } \\
\text { laporan } \\
\text { keuangan } \\
\end{array}$ & $\begin{array}{c}\text { Menampilkan } \\
\text { halaman yang } \\
\text { berisi tabel total } \\
\text { pemasukan dan } \\
\text { pengeluaran }\end{array}$ & Berhasil \\
\hline $\begin{array}{l}\text { Pengujian } \\
\text { membuka } \\
\text { tampilan } \\
\text { menu kasir }\end{array}$ & $\begin{array}{c}\text { Login } \\
\text { menggunakan } \\
\text { akun dengan } \\
\text { level kasir }\end{array}$ & $\begin{array}{c}\text { Menampilkan } \\
\text { halaman yang } \\
\text { berisi tabel } \\
\text { daftar produk } \\
\text { beserta detail } \\
\text { transaksi }\end{array}$ & Berhasil \\
\hline $\begin{array}{l}\text { Pengujian } \\
\text { tombol } \\
\text { tambah ke } \\
\text { keranjang }\end{array}$ & $\begin{array}{c}\text { Menekan } \\
\text { tombol tambah } \\
\text { ke keranjang }\end{array}$ & $\begin{array}{c}\text { Menampilkan } \\
\text { data produk } \\
\text { yang dipilih } \\
\text { beserta quantity } \\
\text { dan harga } \\
\text { produk yang } \\
\text { dipilih }\end{array}$ & Berhasil \\
\hline $\begin{array}{l}\text { Pengujian } \\
\text { tombol } \\
\text { update qty }\end{array}$ & $\begin{array}{l}\text { Menekan } \\
\text { tombol update } \\
\text { qty pada pojok } \\
\text { kanan bawah } \\
\text { tabel transaksi }\end{array}$ & $\begin{array}{l}\text { Menjumlahkan } \\
\text { harga produk } \\
\text { yang dipilih } \\
\text { sesuai dengan } \\
\text { quantity yang } \\
\text { dipesan }\end{array}$ & Berhasil \\
\hline $\begin{array}{l}\text { Pengujian } \\
\text { tombol hapus }\end{array}$ & $\begin{array}{c}\text { Menekan } \\
\text { tombol hapus } \\
\text { pada bagian } \\
\text { kanan tabel } \\
\text { transaksi }\end{array}$ & $\begin{array}{c}\text { Menghapus } \\
\text { data transaksi } \\
\text { dari daftar tabel } \\
\text { transaksi }\end{array}$ & Berhasil \\
\hline $\begin{array}{c}\text { Pengujian } \\
\text { tombol } \\
\text { batalkan } \\
\text { transaksi }\end{array}$ & $\begin{array}{l}\text { Menekan } \\
\text { tombol batalkan } \\
\text { transaksi }\end{array}$ & $\begin{array}{c}\text { Menghapus } \\
\text { semua data } \\
\text { transaksi yang } \\
\text { ditampilkan }\end{array}$ & Berhasil \\
\hline $\begin{array}{c}\text { Pengujian } \\
\text { sukses } \\
\text { submit form } \\
\text { input } \\
\end{array}$ & $\begin{array}{l}\text { Mengisi form } \\
\text { input dengan } \\
\text { lengkap dan } \\
\text { sesuai format }\end{array}$ & $\begin{array}{l}\text { Menyimpan } \\
\text { data input }\end{array}$ & Berhasil \\
\hline $\begin{array}{l}\text { Pengujian } \\
\text { gagal submit } \\
\text { form input }\end{array}$ & $\begin{array}{c}\text { Mengosongkan } \\
\text { sebagian atau } \\
\text { semua form } \\
\text { input }\end{array}$ & $\begin{array}{c}\text { Menampilkan } \\
\text { pemberitahuan } \\
\text { bahwa field } \\
\text { tidak boleh } \\
\text { kosong } \\
\end{array}$ & Berhasil \\
\hline $\begin{array}{l}\text { Pengujian } \\
\text { kesalahan } \\
\text { pengisian } \\
\text { form input }\end{array}$ & $\begin{array}{l}\text { Mengisi form } \\
\text { input dengan } \\
\text { format yang } \\
\text { tidak sesuai }\end{array}$ & $\begin{array}{l}\text { Menampilkan } \\
\text { pemberitahuan } \\
\text { bahwa } \\
\text { pengisian field } \\
\text { tidak memenuhi } \\
\text { ketentuan }\end{array}$ & Berhasil \\
\hline $\begin{array}{c}\text { Pengujian } \\
\text { tombol } \\
\text { kembali } \\
\end{array}$ & $\begin{array}{c}\text { Menekan } \\
\text { tombol kembali }\end{array}$ & $\begin{array}{c}\text { Kembali ke } \\
\text { halaman } \\
\text { sebelumnya }\end{array}$ & Berhasil \\
\hline $\begin{array}{l}\text { Pengujian } \\
\text { tombol cetak } \\
\text { bukti } \\
\text { transaksi }\end{array}$ & $\begin{array}{c}\text { Menekan } \\
\text { tombol cetak } \\
\text { bukti transaksi }\end{array}$ & $\begin{array}{c}\text { Menampilkan } \\
\text { print preview } \\
\text { dari transaksi } \\
\text { terakhir dan } \\
\text { siap cetak }\end{array}$ & Berhasil \\
\hline
\end{tabular}

IV.

\section{KESIMPULAN DAN SARAN}

Dari hasil pengujian dan analisis aplikasi point of sale toko cabang perusahaan Torani, maka dapat disimpulkan hal-hal sebagai berikut :

1. Berdasarkan pengujian, user admin / manajer dapat melakukan aksi pengelolaan karyawan toko, seperti lihat, tambah, ubah data, dan hapus data karyawan. Admin juga dapat melihat daftar produk dan jumlah stok yang tersedia untuk memantau persediaan barang di toko.

2. Berdasarkan pengujian, user pegawai dapat melakukan aksi pengelolaan barang di toko, seperti lihat, tambah barang baru, tambah stok, ubah data, dan hapus data barang. Pegawai juga dapat melakukan pemesanan barang kepada distributor dengan menggunakan menu pesan yang terhubung dengan internet sehingga dapat terkoneksi dengan database distributor.

3. Berdasarkan pengujian, user kasir dapat melakukan aksi transaksi jual beli dengan baik, seperti memilih barang, mendata barang yang dibeli, menghitung jumlah harga secara otomatis, dan mencetak bukti transaksi.

Berdasarkan pengujian terhadap aplikasi point of sale toko cabang perusahaan Torani yang telah dibuat, maka dapat diberikan beberapa saran sebagai berikut :

1. Aplikasi point of sale toko cabang perusahaan Torani ini dapat dikembangkan lebih lanjut dengan menambahkan fitur seperti logika fuzzy untuk mengecek barang apa yang laris dan tidak serta menghitung berapa banyak jumlah barang yang harus dipesan ke distributor, dan kasir yang full menggunakan sistem barcode.

2. Tampilan hasil cetak bukti transaksi dapat dikembangkan dan disesuaikan dengan bentuk printer untuk kasir yang menggunakan kertas gulung berukuran kecil.

3. Aplikasi point of sale toko cabang dapat diintegrasikan ke dalam sebuah web server bersama aplikasi distributor sehingga data dapat menjadi lebih terpusat pada satu database saja.

\section{DAFTAR PUSTAKA}

[1] Ladjamudin, Al-Bahra Bin, Analisis dan Desain Sistem Informasi, Penerbit Graha Ilmu, Yogyakarta, 2005.

[2] Sholiq, Pemodelan Sistem Informasi Berorientasi Obyek dengan UML, Penerbit Graha Ilmu, Yogyakarta, 2006.

[3] Andi, Mudah dan Cepat Membuat Website dengan Codeigniter, Penerbit Andi, Yogyakarta, 2011.

[4] SE, Tommy, Membuat Sistem Aplikasi Minimarket (Point of Sales) dengan VB 6 \& MYSQL 5, Penerbit Elex Media Komputindo, Jakarta, 2008.

[5] Solichin, Achmad, MySQL dari Pemula Hingga Mahir, Universitas Budi Luhur, Jakarta, 2010. 